\title{
Prevalence of methicillin-resistant Staphylococcus aureus in Iranian children: a systematic review and meta-analysis
}

\author{
Farhad Sarrafzadeh, MD¹, Seyed Mojtaba Sohrevardi, Pharm. D², Hamid Abousaidi, MD , Hossein Mirzaei, PhDc ${ }^{3}$ \\ ${ }^{1}$ Faculty of Medicine, Kerman University of Medical Sciences, Kerman, Iran; ${ }^{2}$ Pharmaceutical Science Research Center, Faculty of pharmacy, Shahid Sadoughi \\ University of Medical Science, Yazd, Iran; ${ }^{3} \mathrm{HIV} / \mathrm{STI}$ Surveillance Research Center, WHO Collaborating Center for HIV Surveillance, Institute for Futures Studies in \\ Health, Kerman University of Medical Sciences, Kerman, Iran
}

Background: Antibiotic resistance is associated with longer hospitalizations, higher treatment costs, and increased morbidity and mortality rates.

Purpose: This study aimed to determine the prevalence of methicillin-resistant Staphylococcus aureus (MRSA) in Iranian children.

Methods: International databases, including Web of Science, PubMed, Embase, and Scopus, and Iranian databases, including Scientific Information Database (www.sid.ir), Magiran, and Iranian Database for Medical Literature (idml.research.ac.ir), were systematically searched for articles published between January 2000 and August 2019. Sources of heterogeneity were determined using subgroup analysis and meta-regression.

Results: Overall, 343 studies were identified; of them, 20 were included in the meta-analysis to estimate the pooled prevalence. The pooled prevalence of MRSA was 42\% (95\% confidence interval $[\mathrm{CI}], 29-55)$ among culture-positive cases of S. aureus, 51\% (95\% CI, 39-62) in hospitalized children, and $14 \%$ (95\% CI, 0.05-27) in healthy children.

Conclusion: The overall pooled prevalence of MRSA in children was $42 \%$. Appropriate infection control measures and effective antibiotic therapy are needed.

Key words: Child, Iran, Meta-analysis, Methicillin resistance Staphylococcus aureus, Prevalence

\section{Key message}

The pooled prevalence of methicillin-resistant Staphylococcus aureus (MRSA) was 42\% among culture-positive cases of $S$. aureus, $51 \%$ in hospitalized children, and $14 \%$ in healthy children. The high prevalence of MRSA in Iranian children may be due to insufficient infection control measures in hospitals, inappropriate use of methicillin, inadequate staff training, and over-prescription of antibiotics in Iran.

\section{Introduction}

Staphylococcus aureus, a gram-positive coccus, is among the most common causes of bacterial infection in humans. ${ }^{1}$ S. aureus is a common cause of nosocomial infection in children and adults. ${ }^{2)}$ This pathogen causes pneumonia; infections of the skin, soft tissue, and bloodstream; and invasive infections such as osteomyelitis and septic arthritis. ${ }^{1)}$

Methicillin is one of the best therapeutic choices for the treatment of $S$. aureusinfection. However, studies have reported that the resistance of $S$. aureus to methicillin is increasing. ${ }^{3-5)}$ Methicillin-resistant $S$. aureus (MRSA) has become a major problem in children over the past few decades. Antibiotic resistance is associated with longer hospitalizations, higher treatment costs, and increased morbidity and mortality rates. Children are an important source of MRSA and may play a central role in its distribution in community and healthcare settings. $\left.{ }^{6}\right)$ A study estimated that the incidence of MRSA infection in children increased 10-fold between 1999 and 2008 in the USA. ${ }^{7)}$

Several studies have reported the prevalence of MRSA in different parts of Iran; however, their results are conflicting and no comprehensive analysis has been performed to date. Therefore, a reliable study is needed to estimate the prevalence of MRSA infection in children and assist in its management in children. Thus, this study aimed to investigate the true prevalence of MRSA infection in Iranian children using a systematic review and metaanalysis.

\section{Methods}

\section{Search strategy}

International databases, including Web of Science, PubMed, Embase, and Scopus, and Iranian databases, including Scientific Information Database (www.sid.ir), Magiran, and Iranian Database for Medical Literature (idml.research.ac.ir), were systematically searched for relevant articles published between January 2000 and August 2019. The search was restricted to articles published in the English and Persian languages and conducted using the following keywords in the titles and abstracts: Staphyl ococcus aureus, $S$. aureus, resistance, methicillin, methicillin- 


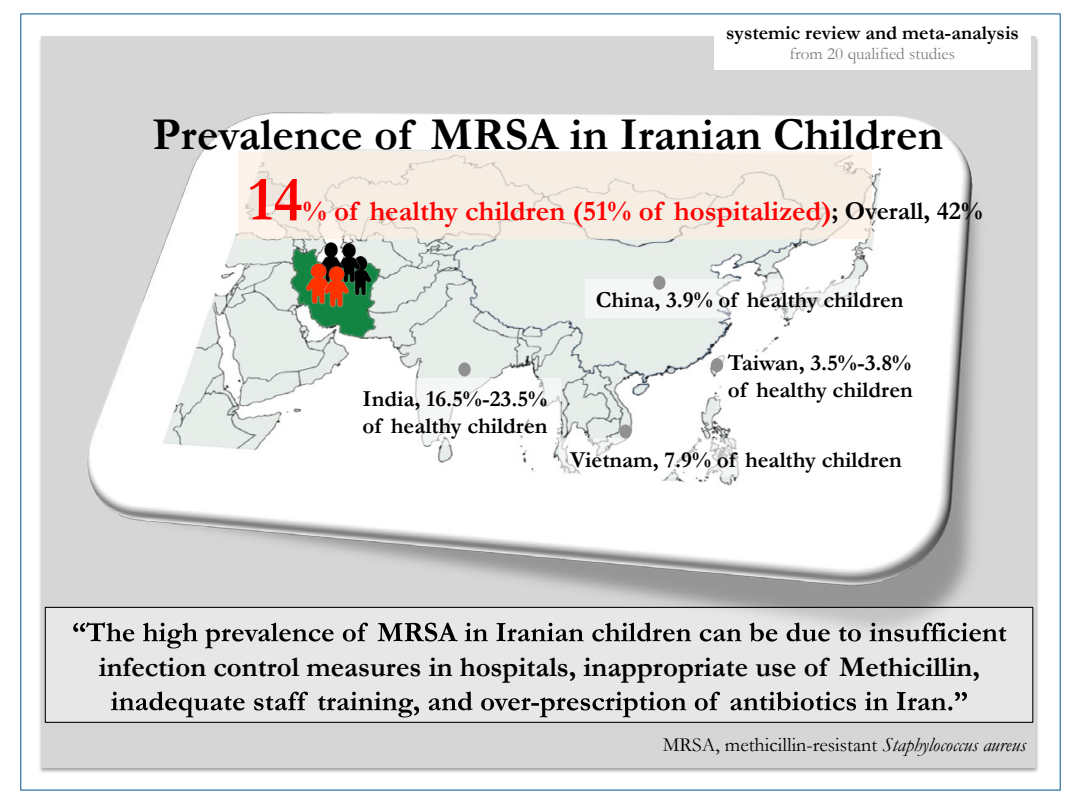

Graphic abstract

resistant Staphylococcus aureus, MRSA, child*, pediatric, infant, Iran, Persian, and Persia. All keywords were searched electronically using 2 Boolean operators (AND, OR).

\section{Inclusion and exclusion criteria}

Two reviewers examined the search results. The article selection process consisted of 3 phases: title, abstract, and full-text. The inclusion criteria were as follows: (1) cross-sectional study, (2) use of standard methods to test methicillin resistance, (3) estimation of the prevalence of methicillin resistance, and (4) inclusion of children aged 1-14 years. The exclusion criteria were as follows: (1) interventional or other study type that did not use the crosssectional method, (2) animal study, (3) review article, (4) consideration of other bacteria types, and (5) inclusion of individuals older than 14 years of age.

\section{Quality assessment and risk of bias}

The included studies were assessed for quality using the Joanna Briggs Institute Prevalence Critical Appraisal Tool..$^{8}$ This tool uses 9 items to examine the validity of the included studies in the meta-analysis. The evolution score ranged from 0 to 9 , with $<4$ considered "low quality," 4-6 considered "moderate quality," and $>6$ considered "high quality."

\section{Data extraction}

A data extraction form was designed to extract the following variables: (1) first author, (2) year of publication, (3) number of investigated patients, (4) number of $S$. aureus-infected individuals, (5) number of MRSA-infected individuals, (6) research environment, (7) MRSA diagnostic method, and (8) study location (province).

\section{Statistical analysis}

The Metaprop program was implemented to perform meta-

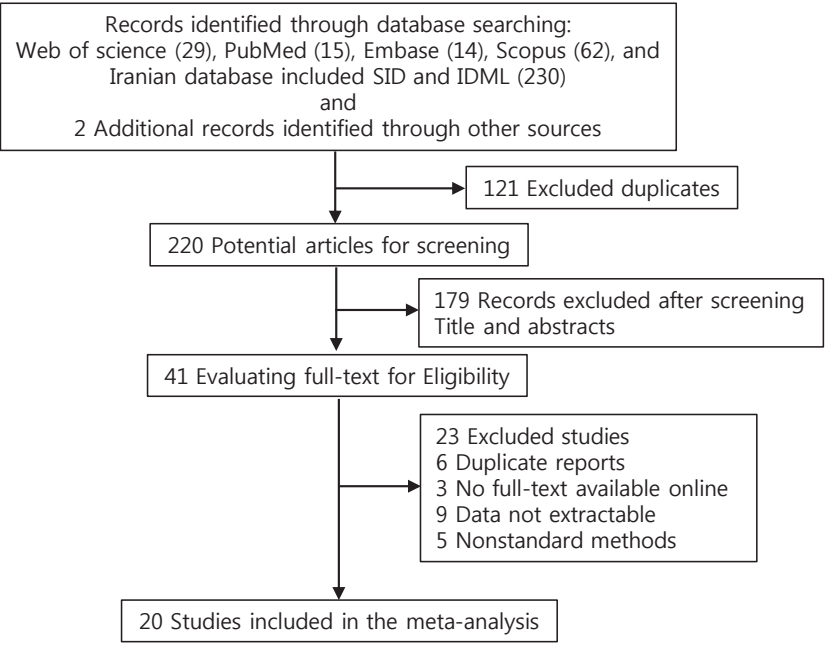

Fig. 1. Flow diagram of the literature search and study selection processes. SID, Scientific Information Database; IDML, Iranian Database for Medical Literature.

analyses of proportions in Stata 12 (StataCorp LP., College Station, TX, USA). ${ }^{9}$ Heterogeneity between the included studies was quantified using the $P$ statistic. Due to the high level of heterogeneity, a random-effects model was used to calculate the pooled prevalence. The estimated prevalence of MRSA is presented as percentages with $95 \%$ confidence intervals (CIs) in the forest plot.

\section{Results}

Overall, 343 studies were identified; however, after title and abstract screening and the removal of duplicate studies $(n=121)$ and those not relevant to the prevalence of MRSA ( $n=179)$, the full-text of 41 reports was reviewed to assess for eligibility. Of those 41 studies, 21 were excluded and only 20 studies were 
Table 1. Characteristics of the studies included in the meta-analysis

\begin{tabular}{|c|c|c|c|c|c|c|c|c|c|c|c|}
\hline Study & $\begin{array}{l}\text { Published } \\
\text { year }\end{array}$ & Time of study & Source of sputum & $\begin{array}{c}\text { Research } \\
\text { environment }\end{array}$ & $\begin{array}{l}\text { Diagnostic } \\
\text { method }\end{array}$ & Province & $\begin{array}{l}\text { No.of S. } \\
\text { aureus- } \\
\text { infected } \\
\text { patients }\end{array}$ & $\begin{array}{l}\text { No. of } \\
\text { MRSA }\end{array}$ & $\begin{array}{l}\text { Pre- } \\
\text { alence }\end{array}$ & $\begin{array}{l}\text { Type of } \\
\text { infection }\end{array}$ & $\begin{array}{c}\text { JBIPCAT } \\
\text { quality } \\
\text { assessment }\end{array}$ \\
\hline Bahmani, et al. $^{10)}$ & 2013 & 2013 & Blood & Neonate ward & Disk diffusion & Kordistan & 20 & 16 & 80 & $\begin{array}{l}\text { Active } \\
\text { infection }\end{array}$ & 5 \\
\hline Besharati, et al. ${ }^{11)}$ & 2019 & $\begin{array}{l}\text { September } \\
2015 \text { to April } \\
2016\end{array}$ & Blood & $\begin{array}{l}\text { Reference hos- } \\
\text { pital }\end{array}$ & Disk diffusion & $\begin{array}{c}\text { North } \\
\text { Khorasan }\end{array}$ & 58 & 31 & 53 & $\begin{array}{l}\text { Active } \\
\text { infection }\end{array}$ & 5 \\
\hline \multirow[t]{4}{*}{ Dormanesh, et al. ${ }^{12)}$} & \multirow[t]{4}{*}{2015} & \multirow[t]{4}{*}{2013} & \multirow{4}{*}{$\begin{array}{l}\text { Blood, UTIs, } \\
\text { respiratory tract } \\
\text { infections }\end{array}$} & \multirow[t]{4}{*}{ Hospital } & Disk diffusion & Tehran & 66 & 19 & 28.7 & $\begin{array}{c}\text { Active } \\
\text { infection }\end{array}$ & \multirow[t]{4}{*}{7} \\
\hline & & & & & Disk diffusion & Isfahan & 67 & 22 & 32.83 & $\begin{array}{c}\text { Active } \\
\text { infection }\end{array}$ & \\
\hline & & & & & Disk diffusion & Mashhad & 56 & 13 & 23.21 & $\begin{array}{l}\text { Active } \\
\text { infection }\end{array}$ & \\
\hline & & & & & Disk diffusion & Shiraz & 66 & 25 & 37.87 & $\begin{array}{l}\text { Active } \\
\text { infection }\end{array}$ & \\
\hline Ghadiri, et al. ${ }^{13)}$ & 2011 & $\begin{array}{l}\text { January } 2007 \\
\text { to April } 2008\end{array}$ & Nasal & Hospital & Disk diffusion & Kermanshah & 101 & 97 & 96 & Carriers & 8 \\
\hline Maham, et al. ${ }^{14)}$ & 2018 & $\begin{array}{c}\text { October } 2014 \\
\text { to November } \\
2016\end{array}$ & Blood & Hospital & E-tests & Tehran & 38 & 20 & 52.6 & $\begin{array}{l}\text { Active } \\
\text { infection }\end{array}$ & 8 \\
\hline Mahmoudi, et al. ${ }^{15)}$ & 2019 & 2016 & $\begin{array}{l}\text { Wound, trachea, } \\
\text { eye, blood, } \\
\text { inguinal region, } \\
\text { abscess, lymph } \\
\text { nodes, and bone }\end{array}$ & $\begin{array}{l}\text { Hospital Children's } \\
\text { Medical Center } \\
\text { Hospital }\end{array}$ & Disk diffusion & Tehran & 120 & 52 & 43 & $\begin{array}{l}\text { Active } \\
\text { infection }\end{array}$ & 9 \\
\hline $\begin{array}{l}\text { Mazloomi } \\
\text { Nobandegani, } \\
\text { et al. }^{16)}\end{array}$ & 2016 & $\begin{array}{l}\text { March } 2011 \text { to } \\
\text { February } 2012\end{array}$ & $\begin{array}{l}\text { Spontaneous } \\
\text { sputum }\end{array}$ & $\begin{array}{l}\text { Children Medical } \\
\text { Center }\end{array}$ & Disk diffusion & Tehran & 93 & 40 & 43 & Carriers & 8 \\
\hline $\begin{array}{l}\text { Poormohammadi, } \\
\text { et al. }{ }^{17)}\end{array}$ & 2016 & $\begin{array}{c}\text { November } 2013 \\
\text { to December } \\
2014\end{array}$ & Nasal & Pediatric ward & Disk diffusion & Kermanshah & 41 & 13 & 31.7 & Carriers & 5 \\
\hline Pourakbari, et al. ${ }^{18)}$ & 2017 & & Nasal & $\begin{array}{c}\text { Referral pediatric } \\
\text { hospital }\end{array}$ & Disk diffusion & Tehran & 146 & 29 & 19.8 & Carriers & 8 \\
\hline Pourakbari, et al. ${ }^{19)}$ & 2018 & $\begin{array}{l}\text { March } 2011 \text { to } \\
\text { September } \\
2016\end{array}$ & Blood & $\begin{array}{l}\text { Children Medical } \\
\text { Center Hospital }\end{array}$ & Oxacillin disk & Tehran & 246 & 116 & 47 & $\begin{array}{l}\text { Active } \\
\text { infection }\end{array}$ & 7 \\
\hline Pourakbari, et al. ${ }^{20)}$ & 2012 & $\begin{array}{c}\text { December } \\
2005 \text { to } \\
\text { January } 2001\end{array}$ & Blood & $\begin{array}{l}\text { Children Medical } \\
\text { Center Hospital }\end{array}$ & Disk diffusion & Tehran & 178 & 141 & 79 & $\begin{array}{l}\text { Active } \\
\text { infection }\end{array}$ & 7 \\
\hline Sabouni, et al. $^{21)}$ & 2014 & 2012 & $\begin{array}{l}\text { Skin and soft } \\
\text { tissue, blood, } \\
\text { urinary, res- } \\
\text { piratory, and } \\
\text { eyeinfection }\end{array}$ & $\begin{array}{l}\text { Referral children's } \\
\text { hospital }\end{array}$ & E-tests & Tehran & 133 & 64 & 48 & $\begin{array}{l}\text { Active } \\
\text { infection }\end{array}$ & 5 \\
\hline Sabouni, et al. ${ }^{22)}$ & 2013 & $\begin{array}{l}\text { November } \\
2011 \text { and } \\
\text { March } 2013\end{array}$ & & $\begin{array}{l}\text { Children medical } \\
\text { center, an Iranian } \\
\text { referral Hospital }\end{array}$ & Disk diffusion & Tehran & 98 & 77 & 79 & $\begin{array}{c}\text { Active } \\
\text { infection }\end{array}$ & 7 \\
\hline Sasan, et al. ${ }^{23)}$ & 2014 & $\begin{array}{l}\text { March 20th } \\
2006 \text { to March } \\
\text { 19th } 2012\end{array}$ & $\begin{array}{l}\text { Blood, bone } \\
\text { puncture, joint } \\
\text { fluid and lymph } \\
\text { node aspiration }\end{array}$ & Pediatric wards & Oxacillin discs & $\begin{array}{l}\text { Central } \\
\text { Khorasan }\end{array}$ & 23 & 17 & 74 & $\begin{array}{c}\text { Active } \\
\text { infection }\end{array}$ & 5 \\
\hline Rezaei, et al. ${ }^{24)}$ & 2013 & & Nasal and Skin & Hospital & Disk diffusion & Tehran & 39 & 13 & 33 & Carriers & 5 \\
\hline Sedighi, et al. ${ }^{25)}$ & 2011 & $\begin{array}{l}\text { September } \\
2007 \text { and } \\
\text { March } 2008\end{array}$ & Nasal & Day care centers & Oxacillin disk & Hamadan & 148 & 6 & 4.1 & Carriers & 6 \\
\hline Sadeghi, et al. ${ }^{26)}$ & 2017 & & Nasal & $\begin{array}{l}\text { Preschool and } \\
\text { school children }\end{array}$ & Disk diffusion & $\begin{array}{c}\text { West } \\
\text { Azarbayjan }\end{array}$ & 81 & 12 & 14.8 & Carriers & 6 \\
\hline $\begin{array}{l}\text { Mobasherizadeh, } \\
\text { et al. }{ }^{27)}\end{array}$ & 2016 & $\begin{array}{l}\text { April } 2013 \text { to } \\
\text { March } 2014\end{array}$ & Nasal & kindergarten & & Isfahan & 115 & 25 & 21.7 & Carriers & 8 \\
\hline Nikfar, et al. ${ }^{28)}$ & 2015 & $\begin{array}{l}\text { September } \\
2010 \text { to June } \\
2011\end{array}$ & Nasal & $\begin{array}{l}\text { Day care center } \\
\text { and school }\end{array}$ & & Khouzestan & 235 & 11 & 4.6 & Carriers & 9 \\
\hline Soltani, et al. ${ }^{29)}$ & 2014 & $\begin{array}{c}\text { July } 2012 \text { and } \\
\text { March } 2013\end{array}$ & Nasal & $\begin{array}{l}\text { Health care } \\
\text { centers }\end{array}$ & Disk diffusion & Isfahan & 92 & 33 & 35.8 & Carriers & 7 \\
\hline
\end{tabular}

MRSA, methicillin-resistant Staphylococcus aureus; JBIPCAT, Joanna Briggs Institute Prevalence Critical Appraisal Tool; UTI, urinary tract infection. 
included in the meta-analysis. The study selection and exclusion processes are presented in Fig. 1.

The 20 included studies were conducted in 10 provinces, including Tehran $(n=9)$; Isfahan $(n=2)$; Kermanshah $(n=2)$; Tehran, Isfahan, Fars, and central Khorasan $(n=1)$; and Hamedan, Kordistan, Azarbayjan, North Khorasan, and Khouzestan $(n=6)$. Publication dates ranged from 2011 to 2019. The evaluation scores ranged from 4 to 9 ; none were scored $\leq 4,8$ were scored 4-6, and 12 were scored $\geq 7$. General information and data of the articles are summarized in Table 1. ${ }^{10-29)}$

Heterogeneity was found between studies $(P=95.36, P<0.001$ for hospitalized children and $P=9415.2, P<0.001$ for healthy children). The random-effects model was used in all analyses.

The prevalence of MRSA among culture-positive cases of $S$. aureus was 42\% (95\% CI, 29-55). The prevalence in hospitalized children was 51\% (95\% CI, 39-62), while that in healthy children

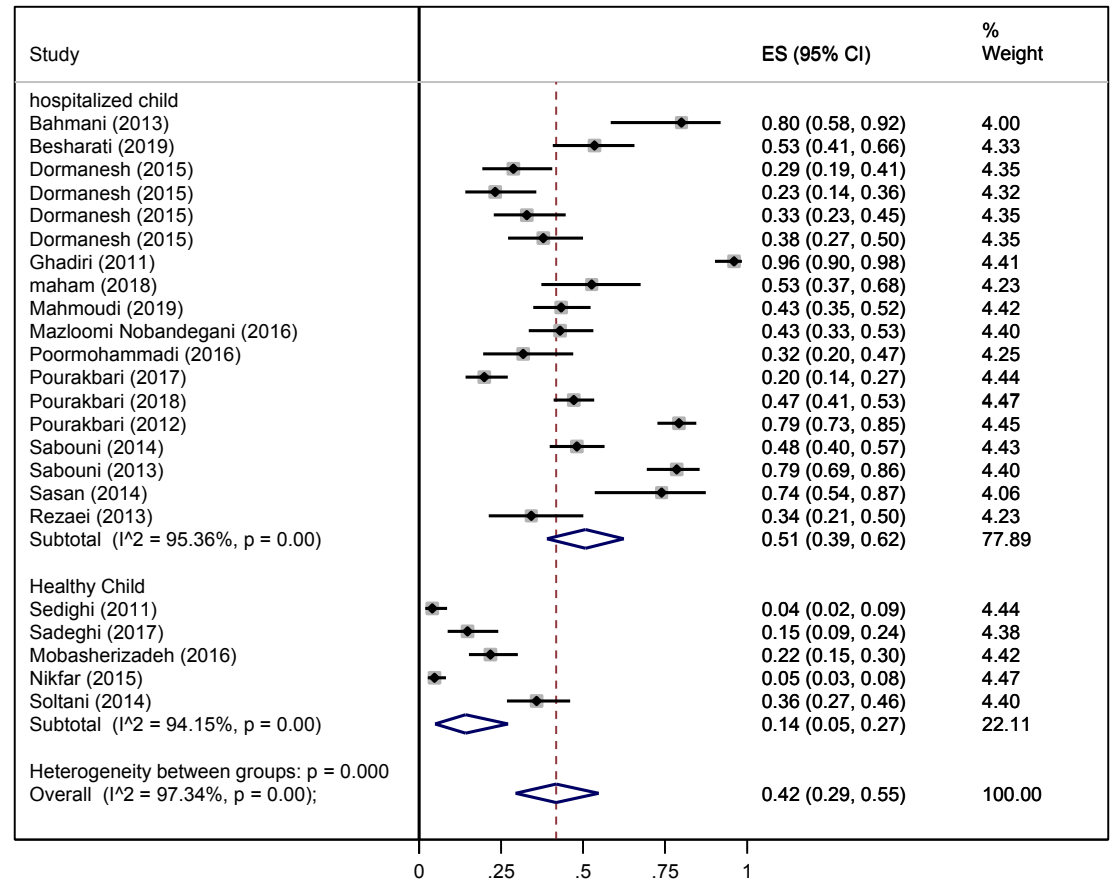

Fig. 2. Meta-analysis of the prevalence of methicillin-resistant Staphylococcus aureus in Iranian children by research environment. $\mathrm{ES}$, effect size; $\mathrm{Cl}$, confidence interval.

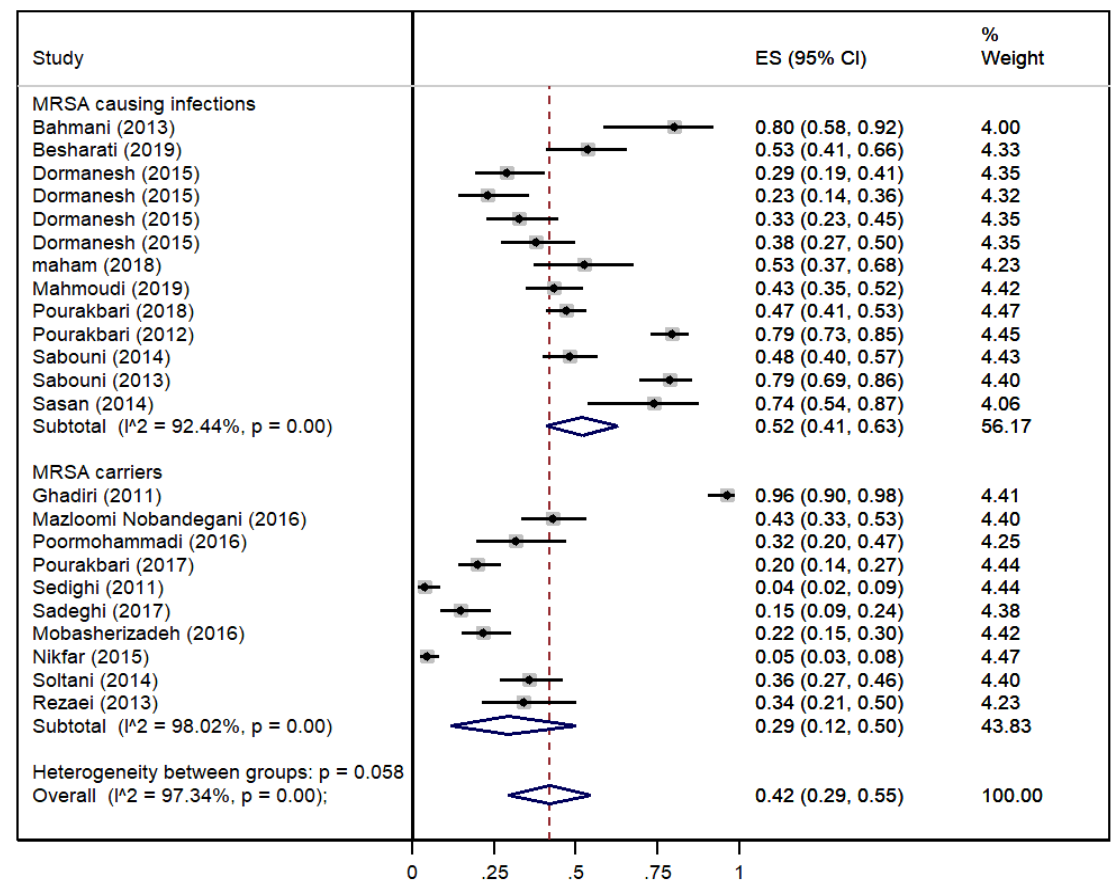

Fig. 3. Meta-analysis of the prevalence of methicillin-resistant Staphylococcus aureus (MRSA) in Iranian children by infection type (active or latent). ES, effect size; Cl, confidence interval. 
was 14\% (95\% CI, 0.05-27) Fig. 2 shows forest plots of the prevalence of MRSA among Iranian children.

Subgroup analysis based on infection type (active or latent $S$. aureusinfection) showed that the prevalence of MRSA in patients with active infection was 52\% (95\% CI, 41-63), while that of patients with latent infection was $29 \%$ (95\% CI, 12-15) (Fig. 3).

A meta-regression method was used to identify the source of heterogeneity, including study period, sample source, study area, research environment (hospitalized or healthy children), and sample size. The results showed that the prevalence of MRSA was associated with the research environment $(P=0.004)$ and study period $(P=0.03)$.

A subgroup analysis according to study period, sample source, geographic area, and evaluation score is shown in Table 2. The prevalence of MRSA decreased from the earliest to the most recent period, the prevalence in blood samples was the highest, and the prevalence of MRSA was the same in the high- and moderate-quality studies (Table 2).

\section{Discussion}

In this study, a meta-analysis was performed to determine and summarize the prevalence of MRSA in Iranian children. The

Table 2. Subgroup analysis of MRSA by study period, sample source, and geographic area

\begin{tabular}{|c|c|c|c|c|}
\hline Variable & $\begin{array}{l}\text { No. of } \\
\text { study }\end{array}$ & $\begin{array}{l}\text { MRSA prevalence } \\
\qquad(95 \% \mathrm{CI})\end{array}$ & $1^{2}$ & $\begin{array}{l}P \text { value } \\
\text { of }\left.\right|^{2}\end{array}$ \\
\hline \multicolumn{5}{|l|}{ Study period } \\
\hline $2000-2004$ & 1 & $79(73-85)$ & - & - \\
\hline 2005-2009 & 3 & $58(0-100)$ & - & - \\
\hline 2010-2014 & 9 & $42(24-61)$ & $97.2 \%$ & $<0.001$ \\
\hline 2015-2019 & 4 & $40(22-59)$ & $90.9 \%$ & $<0.001$ \\
\hline \multicolumn{5}{|l|}{ Source of sample } \\
\hline Blood & 5 & $63(45-78)$ & $92.45 \%$ & $<0.001$ \\
\hline Nasal & 8 & $27(8-27)$ & $98.39 \%$ & $<0.001$ \\
\hline Multisite & 7 & $44(33-55)$ & $89.17 \%$ & $<0.001$ \\
\hline \multicolumn{5}{|l|}{ Geographic areas } \\
\hline Central $^{a)}$ & 13 & $43(32-55)$ & $94.79 \%$ & $<0.001$ \\
\hline Northern ${ }^{\mathrm{b})}$ & 1 & $15(9-24)$ & - & - \\
\hline Western ${ }^{c)}$ & 4 & $53(2-99)$ & $99.10 \%$ & $<0.001$ \\
\hline Eastern ${ }^{\mathrm{d})}$ & 3 & $49(22-76)$ & - & - \\
\hline South ${ }^{\mathrm{e}}$ & 2 & $10(6-13)$ & - & - \\
\hline Overal & 20 & $42(29-55)$ & $97.34 \%$ & $<0.001$ \\
\hline \multicolumn{5}{|l|}{ Evaluation score } \\
\hline 4 and less (low quality) & 0 & - & - & - \\
\hline 4-6 (moderate qualiy) & 8 & $40(20-61)$ & $95.72 \%$ & $<0.001$ \\
\hline 7 and more (high quality) & 12 & $43(27-59)$ & $97.80 \%$ & $<0.001$ \\
\hline
\end{tabular}

MRSA, methicillin-resistant Staphylococcus aureus; Cl, confidence interval. ${ }^{a}$ Chaharmahal and Bakhtiari, Isfahan, Kohgiluyeh, and Boyer-Ahmad, Markazi, Qom, Semnan, Tehran, and Yazd provinces. ${ }^{b}$ Ardabil, East Azerbaijan, West Azerbaijan, Zanjan, Gilan, Golestan, Mazandaran, and Qazvin provinces. ${ }^{c}$ Hamadan, llam, Kermanshah, Kurdistan, and Lorestan

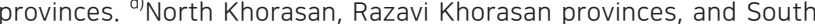
Khorasan provinces. e) Bushehr, Fars, Hormozgan, Kerman, Khuzestan, Sistan, and Baluchestan provinces. prevalence of MRSA among culture-positive cases of $S$. aureus was $42 \%$ (95\% CI, 29-55), that among hospitalized children was 51\% (95\% CI, 39-62), and that among healthy children was 14\% (95\% CI, 0.05-27).

This study revealed that the prevalence of MRSA was $14 \%$ among healthy children recruited from the community, which is much higher than the values reported in China $(3.9 \%),{ }^{30)}$ Vietnam (7.9\%), ${ }^{31)}$ and Taiwan $(3.5 \%-3.8 \%)^{31)}$ but lower than that reported in India (16.5-23.5). ${ }^{31)}$ In addition, the prevalence of MRSA among children recruited in the hospitals was 51\%, much higher than that reported in China (4.4\%) and the AsiaPacific region (0.7\%-10.4\%). The high prevalence of MRSA in Iranian children may be due to insufficient infection control measures in hospitals, inappropriate use of methicillin, inadequate staff training, and the over-prescription of antibiotics in Iran. ${ }^{32)}$ Another important reason for the high prevalence of MRSA in Iran is the lack of a good microbiology diagnostic facility for diagnosing infections. Most of the included studies in this metaanalysis used disk diffusion or the Kirby-Bauer method for MRSA detection. However, based on Clinical \& Laboratory Standards Institute guidelines, this method is not accurate or reliable for MRSA detection. ${ }^{33,34)}$

Overlap of the prevalence of MRSA in Iranian children was $42 \%$, the same as that in Iranian adults. ${ }^{35)}$ Nevertheless, in China, the prevalence of MRSA in adults ${ }^{36}$ was higher than that in children. ${ }^{30)}$

The results of the subgroup analysis indicated that the prevalence of MRSA was much higher among hospitalized children than among healthy children, a result that is consistent with that of another study. ${ }^{30}$ This can be explained by several factors such as the crowded hospital environment, increased contact between healthcare workers and patients, poor attention to infection control protocols, poor adherence to hand hygiene by healthcare workers, and placement of patients with MRSA infections with other patients in the same rooms, all of which increase the risk of MRSA transmission. ${ }^{37,38)}$

A subgroup analysis based on infection type (active versus latent) showed that the prevalence of MRSA in patients with active infection was $52 \%$, while that in patients with latent infection was 29\%. In this study, the prevalence of MRSA was lower in individuals with latent $S$. aureus infection than that in patients with active infection. Patients colonized with MRSA are at higher risk of developing subsequent infections ${ }^{39-41)}$ and serve as a reservoir for its transmission to others. ${ }^{42,43)}$ Therefore, active surveillance to identify MRSA carriers and eradicate MRSA colonization is essential. Subgroup analysis results showed that the prevalence of MRSA decreased from the earliest to the most recent period. One explanation for the decrease in the prevalence of MRSA in Iran is the small number of articles in 2000-2004 and 2005-2009, as only 4 studies on the subject were published before 2010 .

In this study, another subgroup analysis was conducted by geographic area. The majority of the included studies in this metaanalysis were performed in Tehran (the capital of Iran located in 
the central part of Iran) since many referral hospitals are located in this city and many patients are referred to these hospitals from different parts of the country to seek diagnosis and treatment.

This study has several limitations. First, because the prevalence of MRSA was not studied in different regions of Iran, our results cannot indicate the nationwide prevalence of MRSA. Second, there was a potential for publication bias similar to that seen in other meta-analyses, and only published studies were included in this review. Third, there was significant heterogeneity among the included studies. Although the data were analyzed according to subgroups of geographic areas, study period, study sample, and sample size, the heterogeneity was not significantly decreased.

In conclusion, in this systematic review and meta-analysis, we summarized the high prevalence of MRSA in Iranian children. We found that the prevalence of MRSA was higher in hospitalized children than in healthy children and higher in individuals with active infection than in those with latent infection. These results highlight that infection control programs in Iran are ineffective and that appropriate infection control measures and effective antibiotic therapy are needed to control the spread of MRSA in Iran.

\section{Footnotes}

Conflicts of interest: No potential conflict of interest relevant to this article was reported.

\section{ORCID:}

Farhad Sarrafzadeh @ https://orcid.org/0000-0002-9956-4492

Seyed Mojtaba Sohrevardi (1) https://orcid.org/0000-00020993-3339

Hamid Abousaidi @ https://orcid.org/0000-0003-3334-6596

Hossein Mirzaei $@$ https://orcid.org/0000-0002-8033-9762

\section{References}

1. Lowy FD. Staphylococcus aureus infections. NEngl J Med 1998;339:52032.

2. Kaplan SL. Staphylococcus aureus infections in children: the implications of changing trends. Pediatrics 2016;137:e20160101.

3. Tokajian S, Haddad D, Andraos R, Hashwa F, Araj G. Toxins and antibiotic resistance in Staphylococcus aureus isolated from a major hospital in lebanon. ISRN Microbiol 2011;2011:812049.

4. Virdis S, Scarano C, Cossu F, Spanu V, Spanu C, De Santis EP. Antibiotic resistance in Staphylococcus aureus and coagulase negative staphylococci isolated from goats with subclinical mastitis. Vet Med Int 2010;2010: 517060.

5. Udo EE, Al-Sweih N, Dhar R, Dimitrov TS, Mokaddas EM, Johny M, et al. Surveillance of antibacterial resistance in Staphylococcus aureus isolated in Kuwaiti hospitals. Med Princ Pract 2008;17:71-5.

6. Hisata K, Kuwahara-Arai K, Yamanoto M, Ito T, Nakatomi Y, Cui L, et al. Dissemination of methicillin-resistant staphylococci among healthy Japanese children. J Clin Microbiol 2005;43:3364-72.

7. Herigon JC, Hersh AL, Gerber JS, Zaoutis TE, Newland JG. Antibiotic management of Staphylococcus aureus infections in US children's hospitals, 1999-2008. Pediatrics 2010;125:e1294-300.

8. Munn Z, Moola S, Lisy K, Riitano D, Tufanaru C. Methodological gui- dance for systematic reviews of observational epidemiological studies reporting prevalence and cumulative incidence data. Int J Evid Based Healthc 2015;13:147-53.

9. Nyaga VN, Arbyn M, Aerts M. Metaprop: a Stata command to perform meta-analysis of binomial data. Arch Public Health 2014;72:39.

10. Bahmani N, Kalantar E, Torabi V. Survey of methicillin-resistant strains of Staphylococci from neonatal septicemia for mecA gene. Life Sci J 2013; 10:303-6.

11. Besharati R, Ghafouri M, Safamanesh S, Khosrojerdi M, Ghazvini K, Nojumi S, et al. Molecular epidemiology of panton-valentine leukocidin harboring hospital-associated methicillin-resistant Staphylococcus aureus in septicemic children, Northeastern Iran, Bojnurd. Jundishapur J Microbiol 2019. In Press. https://doi.org/10.5812/jjm.68183.

12. Dormanesh B, Siroosbakhat S, Khodaverdi Darian E, Afsharkhas L. Methicillin-resistant Staphylococcus aureus isolated from various types of hospital infections in pediatrics: panton-valentine leukocidin, staphylococcal chromosomal cassette mec SCCmec phenotypes and antibiotic resistance properties. Jundishapur J Microbiol 2015;8:e11341.

13. Ghadiri K, Ebrahimi E, Akramipour R, Rezaei M, Khazaei S, Ma A, et al. Nasal carriage rate of community- and hospital-acquired methicillinresistant Staphylococcus aureus in children, Kermanshah, Iran. Iran J Clin Infect Dis 2011;6:117-20.

14. Maham S, Fallah F, Gholinejad Z, Seifi A, Hoseini-Alfatemi SM. Bacterial etiology and antibiotic resistance pattern of pediatric bloodstream infections: a multicenter based study in Tehran, Iran. Ann Ig 2018;30:337- 45.

15. Mahmoudi S, Mamishi S, Mohammadi M, Banar M, Ashtiani MTH, Mahzari M, et al. Phenotypic and genotypic determinants of mupirocin resistance among Staphylococcus aureus isolates recovered from clinical samples of children: an Iranian hospital-based study. Infect Drug Resist 2019;12:137-43.

16. Mazloomi Nobandegani N, Mahmoudi S, Pourakbari B, Hosseinpour Sadeghi R, Najafi Sani M, Farahmand F, et al. Antimicrobial susceptibility of microorganisms isolated from sputum culture of patients with cystic fibrosis: methicillin-resistant Staphylococcus aureus as a serious concern. Microb Pathog 2016;100:201-4.

17. Poormohammadi S, Farahani A, Mohajeri P. Genomic diversity and antimicrobial susceptibility profiling of nasal carriage Staphylococcus aureus isolated from pediatric ward in Western Iran. Saudi J Biol Sci 2019;26:1-7.

18. Pourakbari B, Khodabandeh M, Mahmoudi S, Sabouni F, Aziz-Ahari A, Bahador A, et al. Molecular epidemiology of Staphylococcus aureus nasal colonization among patients and their parents /guardian in an Iranian referral hospital. Microb Pathog 2017;107:75-80.

19. Pourakbari B, Mahmoudi S, Moradzadeh M, Mahzari M, Ashtiani MTH, Tanzifi P, et al. Antimicrobial resistance patterns of the gram-positive bacteria isolated from children with bloodstream infection in an iranian referral hospital: a 6-year study. Infect Disord Drug Targets 2018;18:136-44.

20. Pourakbari B, Sadr A, Ashtiani MT, Mamishi S, Dehghani M, Mahmoudi $\mathrm{S}$, et al. Five-year evaluation of the antimicrobial susceptibility patterns of bacteria causing bloodstream infections in Iran. J Infect Dev Ctries 2012;6: $120-5$.

21. Sabouni F, Mahmoudi S, Bahador A, Pourakbari B, Sadeghi RH, Ashtiani MT, et al. Virulence factors of Staphylococcus aureus isolates in an Iranian Referral Children's Hospital. Osong Public Health Res Perspect 2014;5: 96-100.

22. Sabouni F, Ranjbari R, Pourakbari B, Mahmoudi S, Teymuri M, Ashtiani MT, et al. Staphylococcus aureus infections in children in an Iranian referral pediatric hospital. J Prev Med Hyg 2013;54:205-7.

23. Sasan M, Donyadide N, Askari E, Naderi-Nasab M. Invasive communityacquired Staphylococcus aureus among pediatric population of Eastern Iran. Iran J Microbiol 2014;6:84-6.

24. Rezai S, Ghadikolaii FP, Ahanjan M, Valadan R, Ahangarkani F, Rezai MS, et al. Prevalence of nasal carriage methicillin-resistant Staphylococcus aureus with mecA gene among healthy primary school boys in North of Iran; a cross-sectional study. Int J Pediatr 2017;5:6515-25.

25. Sedighi I, Moez HJ, Alikhani MY. Nasal carriage of methicillin resistant Staphylococcus aureus and their antibiotic susceptibility patterns in children attending day-care centers. Acta Microbiol Immunol Hung 2011; 
58:227-34.

26. Sadeghi E, Nasim far A, Karamiyar M, Ghazavi A, Nikibakhsh AA, Noroozi M. Frequency of methicillin-resistant Staphylococcus aureus nasal colonization among preschool and school children under 14 years old in Urmia. Urmia Med J 2017;27:1041-7.

27. Mobasherizadeh S, Shojaei H, Havaei SA, Mostafavizadeh K, Davoodabadi F, Khorvash F, et al. Nasal carriage screening of community-associated methicillin resistant Staphylococcus aureus in healthy children of a developing country. Adv Biomed Res 2016;5:144.

28. Nikfar R, Shamsizadeh A, Ziaei Kajbaf T, Kamali Panah M, Khaghani S, Moghddam M. Frequency of methicillin-resistant Staphylococcus aureus nasal carriage in healthy children. Iran J Microbiol 2015;7:67-71.

29. Soltani B, Taghavi Ardakani A, Moravveji A, Erami M, Haji Rezaei M, Moniri R, et al. Risk Factors for methicillin resistant Staphylococcus aureus nasal colonization of healthy children. Jundishapur J Microbiol 2014; 7:e20025.

30. Lin J, Peng Y, Xu P, Zhang T, Bai C, Lin D, et al. Methicillin-resistant Staphylococcus aureus nasal colonization in chinese children: a prevalence meta-analysis and review of influencing factors. PLoS One 2016;11: e0159728.

31. Wong JW, Ip M, Tang A, Wei VW, Wong SY, Riley S, et al. Prevalence and risk factors of community-associated methicillin-resistant Staphylococcus aureus carriage in Asia-Pacific region from 2000 to 2016: a systematic review and meta-analysis. Clin Epidemiol 2018;10:1489-501.

32. Soltani J, Pouladfar G, Versporten A, Sharland M, Goossens H, Jafarpour $\mathrm{Z}$, et al. Point prevalence survey of antimicrobial prescription and infection in pediatric and neonatal wards of two Iranian teaching hospitals. Erciyes Med J 2019;41:25-32.

33. CLSI. Performance Standards for Antimicrobial Susceptibility Testing. 27th ed. CLSI supplement M100. Wayne (PA): Clinical and Laboratory Standards Institute, 2017.

34. Maes N, Magdalena J, Rottiers S, De Gheldre Y, Struelens MJ. Evaluation of a triplex PCR assay to discriminate Staphylococcus aureus from coagulase-negative Staphylococci and determine methicillin resistance from blood cultures. J Clin Microbiol 2002;40:1514-7.

35. Dadashi M, Nasiri MJ, Fallah F, Owlia P, Hajikhani B, Emaneini M, et al. Methicillin-resistant Staphylococcus aureus (MRSA) in Iran: A systematic review and meta-analysis. J Glob Antimicrob Resist 2018;12:96-103.
36. Gu FF, Zhang J, Zhao SY, Yang ZR, Zhang YL, Xiao SZ, et al. Risk factors for methicillin-resistant Staphylococcus aureus carriage among residents in 7 nursing homes in Shanghai, China. Am J Infect Control 2016;44: 805-8.

37. Mamishi S, Pourakbari B, Teymuri M, Babamahmoodi A, Mahmoudi S. Management of hospital infection control in iran: a need for implementation of multidisciplinary approach. Osong Public Health Res Perspect 2014;5:179-86.

38. Emaneini M, Beigverdi R, van Leeuwen WB, Rahdar H, Karami-Zarandi M, Hosseinkhani F, et al. Prevalence of methicillin-resistant Staphylococcus aureus isolated from burn patients in Iran: a systematic review and meta-analysis. J Glob Antimicrob Resist 2018;12:202-6.

39. Cadena J, Thinwa J, Walter EA, Frei CR. Risk factors for the development of active methicillin-resistant Staphylococcus aureus (MRSA) infection in patients colonized with MRSA at hospital admission. Am J Infect Control 2016;44:1617-21.

40. Wertheim HF, Vos MC, Ott A, van Belkum A, Voss A, Kluytmans JA, et al. Risk and outcome of nosocomial Staphylococcus aureus bacteraemia in nasal carriers versus non-carriers. Lancet 2004;364:703-5.

41. Smyth DS, Kafer JM, Wasserman GA, Velickovic L, Mathema B, Holzman RS, et al. Nasal carriage as a source of agr-defective Staphylococcus aureus bacteremia. J Infect Dis 2012;206:1168-77.

42. Lauderdale TL, Wang JT, Lee WS, Huang JH, McDonald LC, Huang IW, et al. Carriage rates of methicillin-resistant Staphylococcus aureus (MRSA) depend on anatomic location, the number of sites cultured, culture methods, and the distribution of clonotypes. Eur J Clin Microbiol Infect Dis 2010;29:1553-9.

43. Davis MF, Iverson SA, Baron P, Vasse A, Silbergeld EK, Lautenbach E, et al. Household transmission of meticillin-resistant Staphylococcus aureus and other staphylococci. Lancet Infect Dis 2012;12:703-16.

How to cite this article: Sarrafzadeh F, Sohrevardi SM, Abousaidi H, Mirzaei H. Prevalence of methicillin-resistant Staphylococcus aureus in Iranian children: a systematic review and meta-analysis. Clin Exp Pediatr 2021;64:415-21. https://doi. org/10.3345/cep.2020.00255 